\title{
EUROPEAN UNION - EURASIAN ECONOMIC UNION: COOPERATION OR COMPETITION?
}

\begin{abstract}
The article analyses the differences in the EU's and Russia's approaches to the cooperation between two integration blocs - the European Union (EU) and the Eurasian Economic Union (EAEU), as well as the obstacles to cooperation and the possibilities to find the way out of the current deadlock. Proceeding from the information about the contacts between the EAEU and the EU Member States, the author regards the bilateral relations might be currently more preferable for the EAEU in the absence of substantial dialogue between the European Commission and the Eurasian Economic Commission. The potential of the OSCE structures is emphasized as a ground for future negotiations between the EU and the EAEU. The author concludes that numerous agreements on trade and economic cooperation with the EAEU and its partners, including the interconnection between the Eurasian Economic Union and the Silk Road Economic Belt (SERB) could form the new integration framework for the Greater Eurasia.

Key words: European Union, Eurasian Economic Union, Eurasian Economic Commission, Silk Road Economic Belt, cooperation, trade and economic agreements, integration.

The interaction between the Eurasian Economic Union (EAEU) and the European Union (EU) is a highly crucial issue both for political and academic research due to significant role of regional integration in the contemporary international system and growing cooperation between various regions 1 .

Should we set cooperation against competition? Cooperative competition or competitive cooperation would be a very positive scenario for the EU-Eurasian Union relation, if only competition is fair, without artificial barriers which are mainly political and geopolitical. In the dialogue with the European Union Russia has proposed and consistently promoted equal and mutually beneficial cooperation together with the idea of the common economic and humanitarian space from the Atlantic to the Pacific. Practical cooperation between the EAEU and the EU could become an economic basis for the implementation of such a project. It would allow to avoid a choice either/or, when the country «in-between» is actually faced with an alternative: either with the EU or with Russia -both/ and looks much better ${ }^{2}$.
\end{abstract}

(C) Potemkina Olga Yuryevna - PhD(Political Sciences), Head of Department of the European Integration Studies, Institute of Europe, Russian Academy of Sciences; Professor of the Faculty of the World Politics, Lomonosov Moscow State University. Address: 11-3, Mokhovaya str., Moscow, Russia, 125009. E-mail: olga_potemkina@mail.ru.

DOI: http://dx.doi.org/10.15211/vestnikieran42018610.

${ }^{1}$ Zaslavskaya N. The problems of the EU-EAEU interaction. Upravlencheskoe konsultirovanie, 2017. URL: https://cy berleninka.ru/article/n/problemy-vzaimodeystviya-eaes-i-es (Accessed on 10 June 2018).

2 Ayvazyan A. «Signing the EU-Armenia Comprehensive and Enhanced Partnership Agreement». Analytical Report №23, 2017 (№96). URL: http://instituteofeurope.ru/images/uploads/analitika/an96.pdf (Accessed on 10 June 2018). 
The high degree of economic complementarity and the adherence to the uniform trade rules based on WTO standards ensure the necessary conditions for stable and transparent contacts between the EAEU and the European Union. It is clear that the EU example has been and remains a model for Eurasian economic integration. In the process of constructing the Eurasian Economic Un ion its Member States are interested to apply all the best European practices adjusted to their own national realities. Thus, the similar principles of market liberalization form today the basis of both EU and EAEU models -new trade flows; freedom of movement of goods, services, capital, labor; improvement of quality of life through perfecting quality of goods and services; establishing an institutional system, which is independent of the Member States; elaboration of common rules and checking their application.

The public as well as business community of the EAEU Member States have no objections to internal norms and standards harmonization, upgrading inefficient standards to the level of the advanced ones, health and labour protection, etc. Therefore, it would seem that the economically European and Eurasian regions are interested in cooperation because they successfully complement each other. However, two integration projects still cannot find a basis for cooperation ${ }^{1}$.

\section{Because there are several obstacles}

- Conceptual differences. From the EU side, Wider Europe and European Neighbourhood Policy give main initiative to the European Union and perceive the countries of the Eurasian region as the objects of EU policy. On the contrary, Russia has interpreted «the Greater Europe» as a «common space from Lisbon to Vladivostok» with the possibility of implementing common economic and other projects. The same idea is a basis for the «integrating integrations» promoted by Alexander Lukashenko, the President of Belarus, and the TRANS-Eurasian partnership supported by the Eurasian Economic Commission (EEC).

- Political disagreements. There exist different approaches to the situations directly in the Eurasian region (Abkhazia and South Ossetia, Ukraine), as well as outside the region (Syria). It would seem that political and economic issues could be separated, in case a focus is put only on common interests, pragmatic decisions and promotion of trade relations, without paying attention to political differences. However, the reality demonstrates that it is not true. Russia has attempted to establish EAEU-EU cooperation in 2015. The Position Paper on the EAEU, which outlined the views and possible forms of cooperation, was handed to the EU Commission. In the response letter, the EU leadership noted that the European Union takes a decision on the possibility of cooperation with considering wider political context and implementation of the Minsk agreements. So in this case the EU conditionality principles prevent from the constructive approach to cooperation.

- Institutional problems. On the part of the EU, there is a lack of understanding - which official or institution to negotiate with in the EAEU. Europeans believe that the Eurasian project is developing mainly due to the support of Russia; therefore, fundamental negotiations are likely to be conducted not with the colleagues from Eurasian Economic Commission, but with the Russian leadership. That is why in 2015 the President of the European Commission J.-C. Juncker sent a letter

\footnotetext{
${ }^{1}$ Kondratieva N. The EU-EAEU relations: peculiarities of the contemporary stage. Sovremennaya Evropa, №3, 2018. Научно-аналитический вестник ИЕ РАН, 2018, №4
} 
devoted to communication between the regional integration blocs to President Vladimir Putin, and not to the EAEU institutions ${ }^{1}$.

Actually, the EU-EAEU cooperation should not be subject to any conditionality. As a fact, the EAEU existence has become an objective reality which is difficult to ignore. Wider competencies, which were transferred to the EAEU, modify conditions of foreign trade operations for the EU companies in such areas as customs and tariff regulation, technical regulation, protection of internal measures, phytosanitary and veterinary regulation. That is why the establishment of direct links between the European Commission and the Eurasian Economic Commission would be of practical benefit. The EU partners show interest in cooperation with the EEC on regulatory issues (standardization and technical regulation) at the expert level.

\section{The Eurasian Union and the EU Member States}

However, from the part of the EU Member States, the situation is different. In the medium term, the development of bilateral ties with the EU Member States might be more beneficial for the EAEU. They have already demonstrated interest in bringing closer integration processes in the Euro-Atlantic and Eurasia. A number of important events have recently proved this interest. The meeting between the Eurasian Economic Commission and the Foreign Ministries of Austria and France took place at the EEC Commission's HQ in Moscow. «Vienna process 2017» was launched; Thessaloniki Forum took place in September 2017. «Eurasian Economic Forum: in Search of New Balanced Relations» was held in Verona, where the current developments in the EAEU and the prospects for Eurasian economic integration have been discussed. Worth mentioning is the Joint Declaration on the cooperation between the Government of Greece and the EEC on 24 June, 2017, which provides for cooperation on a broad economic agenda while considering obligations of Greece as the EU Member State.

Therefore, in general, the contacts are sufficient. Initially, they serve to inform the EU business about the Eurasian Economic Union activities: application of sanitary, veterinary and phytosanitary measures, public procurement, financial markets, intellectual property, trade and competition policy, antitrust regulation. In 2016, the President of Kazakhstan N. Nazarbayev launched the initiative to hold an international conference in Brussels with participation of the high-ranking officials. The aim of this proposal was to find possibilities for interaction between the EAEU and the EU. Regrettably, it remains unrealized.

The Organsation for Security and Co-operation in Europe (OSCE) can become a framework for productive contacts via its Platform for Cooperative Security, as this European organization includes both EU Member States and the EAEU. In this regard it is important to develop the dialogue on regional and sub-regional integration and cooperation in the relevant OSCE structures, as well as the development of Eurasian transport links and corridors. For example, for the EAEU it looks very attractive to connect its transport infrastructure with the Trans-European corridors №2 and №9, as well as with the Eurasian corridors «East-West» and «North-South» ${ }^{2}$. Besides, joint EAEU-OSCE

\footnotetext{
${ }^{1}$ Zaslavskaya N. The problems of the EU-EAEU interaction. Upravlencheskoe konsultirovanie, 2017. URL: https:// cyberleninka.ru/article/n/problemy-vzaimodeystviya-eaes-i-es (Accessed on 10 June 2018).

${ }^{2}$ Preiherman Y. Infrastructure Connectivity and Political Stability in Eurasia. Valdai Paper №85, 08.05.2018. URL: Научно-аналитический вестник ИЕ РАН, 2018, №4
} 
projects might be developed on digital transport corridors, digital industrial cooperation, traceability of products, goods, and on harmonization of digital infrastructures, creation of zone docking digital infrastructures ${ }^{1}$.

The EAEU and its Members are interested to strengthen further the regulatory framework for cooperation with the EU candidate countries and European-perspective states of the Western Balkans in areas where this does not contradict with their EU integration commitments. It seems that such an approach would be beneficial for those states; it would allow them to pursue a multi-vector trade and economic policy without sacrificing their interests and their choice in favor of joining the EU. The most relevant example is Serbia, which is interested in the free trade deal with the EAEU. This new free trade agreement is supposed to replace older bilateral Free Trade Agreements (FTAs), which Serbia has with Russia, Belarus, and Kazakhstan and expand the market for its products to Armenia and Kyrgyzstan, which is beneficial for Serbian economy. However the EU does not demonstrate enthusiasm towards Serbia's plans and intentions in this direction and, on the contrary, worries about several points - is this unified trade regime compatible with the SAA between the EU and Serbia? Taking into consideration relevant issues stemming from the accession negotiations, is the unified trade regime with the EAEU compatible with the candidate country status of Serbia? ${ }^{2}$ The normal businesslike relations presuppose discussions of the issues of concern and searching for the way out; but the confrontational agenda would suggest the unpleasant choice: either with the EU or with the Eurasian Union.

The EAEU states need more diversification in their external relations, not only with the EU but also with China, Iran, the Arab countries etc. At the same time, among the Eurasian economic integration priorities there is a study of the options for interconnection between the Eurasian Economic Union and the Silk Road Economic Belt (SREB) or One Belt, One Road (OBOR). The Agreement on Trade and Economic Cooperation between the EAEU and China as well as the interim FTA's with China and Iran were signed at the Astana Economic Forum in May 2018. FTA between the Eurasian Economic Union and Vietnam has already allowed increasing trade turnover for 36\%. In the long term, these agreements could serve as the basis for a new integration framework - the Great Eurasian Partnership, which is designed to harmonize interaction in the regional multilateral institutions.

http://valdaiclub.com/a/valdai-papers/valdai-paper-85-infrastructure-connectivity/ (Accessed on 30 July 2018).

${ }^{1}$ Minasyan K, Minister for Internal Markets, Informatization and ICT. Eurasian Economic Commission. EAEU Digital Agenda. Vienna, 22 January 2018. URL: https://www.osce.org/chairmanship/373513?download=true (Accessed on 30 Julv 2018).

${ }_{2}$ European Parliament. Parliamentary Ouestions. Serbia and unified trade regime with EAEU. URL: http://www.euro parl.europa.eu/sides/getDoc.do?pubRef=-//EP//TEXT+WQ+E-2016-005020+0+DOC+XML+V0//EN\&language=pt. 


\section{References}

Fardella E., Prodi G. The Belt and Road initiative and its impact on Europe. Valdai Paper №82: 02.03.2018. URL: http://valdaiclub.com/a/valdai-papers/valdai-paper-82-the-belt-and-road-initiative/

Minasyan K, Minister for Internal Markets, Informatization and ICT. Eurasian Economic Commission. EAEU Digital Agenda. Vienna, 22 January 2018. URL: https://www.osce.org/chairman ship/373513?download=true.

Preiherman Y. Infrastructure Connectivity and Political Stability in Eurasia. Valdai Paper №85, 08.05.2018 http://valdaiclub.com/a/valdai-papers/valdai-paper-85-infrastructure-connectivity/

Russia and EU: towards new constructive relations on a shared continent. Address by Ambassador Vladimir Chizhov, Permanent Representative of the Russian Federation to the European Union and European Atomic Energy Community, at Cercle de Lorraine diplomatic debate. Brussels, $1 \mathrm{Ju}-$ ne 2018. URL: https://russiaeu.ru/en/news/russia-and-eu-towards-new-constructive-relations-shared-continent.

Statement by Permanent Representative of the Russian Federation to the European Union Ambassador Vladimir Chizhov at the $10^{\text {th }}$ Eurasian Economic Forum (Verona, 20 October 2017). URL: https://russiaeu.ru/en/ambassador-vladimir-chizhov-s-statement-10th-eurasian-economic-forum.

Suslov D. Without a «Common Space»: a New Agenda For Russia-EU Relations. Valdai Paper №49. June 2016 http://valdaiclub.com/files/11424/

DOI: http://dx.doi.org/10.15211/vestnikieran42018610 